\title{
Transatlantica
}

Revue d'études américaines. American Studies Journal

\section{Sarah Rivett, The Science of the Soul in Colonial New} England

Chapel Hill, The University of North Carolina Press, 2011

\section{Thomas Constantinesco}

\section{(2) OpenEdition}

\section{Journals}

Édition électronique

URL : https://journals.openedition.org/transatlantica/6589

DOI : 10.4000/transatlantica.6589

ISSN : 1765-2766

Éditeur

Association française d'Etudes Américaines (AFEA)

Édition imprimée

Date de publication : 31 décembre 2013

Référence électronique

Thomas Constantinesco, "Sarah Rivett, The Science of the Soul in Colonial New England », Transatlantica [En ligne], 2 | 2013, mis en ligne le 30 avril 2014, consulté le 31 janvier 2023. URL : http:// journals.openedition.org/transatlantica/6589; DOI : https://doi.org/10.4000/transatlantica.6589

Ce document a été généré automatiquement le 31 janvier 2023.

\section{(c) (i) (3)}

Creative Commons - Attribution - Pas d'Utilisation Commerciale - Pas de Modification 4.0 International - CC BY-NC-ND 4.0

https://creativecommons.org/licenses/by-nc-nd/4.0/ 


\section{Sarah Rivett, The Science of the Soul in Colonial New England}

Chapel Hill, The University of North Carolina Press, 2011

Thomas Constantinesco

\section{RÉFÉRENCE}

RIVETT, Sarah, The Science of the Soul in Colonial New England,

Chapel Hill, The University of North Carolina Press, 2011, 364 pages, ISBN

978-0-8078-3524-1, \$47,50

1 Arguing for the enduring links between religion and science, not only in Colonial New England, but also across the early modern Atlantic world, this book is about disciplinary pairings, rather than divisions, and about historical and geographical continuities, rather than disruptions. In an impressive display of interdisciplinary scholarship, Sarah Rivett offers a compelling account of the history of Colonial New England, from the times of John Winthrop and John Cotton to the Great Awakening, as driven by a theological and epistemological quest for knowledge that turned paradoxically to the soul as a privileged though immaterial locus of empirical enquiry. She thus proposes to view New England as exemplary of early modern religious and scientific concerns, even as she maintains its centrality and, at certain key periods of its history, even its uniqueness, by demonstrating how "place is essential to the production of scientific knowledge" (9), thereby shedding a new and nuanced light on the vexed issue of American exceptionalism. In the course of six chapters, her "narrative of Atlantic crossings and epistemic transformations" (11) then traces the various responses to what she describes as the "double bind of knowledge" (77) underlying Calvinist Protestantism and post-Reformation scientific pursuits, namely that "desired knowledge was also forbidden knowledge" (11). This double bind characterized the genre of the "testimony of faith" that emerged during the Reformation in response to the Catholic practice of mandatory confession and that 
became central to both New and old England ecclesiastical practice throughout the seventeenth century. As Rivett convincingly reads them, these testimonies reveal the convergence between Puritan theology and natural philosophy, exposing the soul as "a bridge that would link the visible and invisible worlds" (44), "a temporal repository for the hidden secrets of grace" to be explored by way of empirical methods of investigation (45).

2 In Colonial New England, where justification of the "errand into the wilderness" was paramount and entailed setting up a series of controlling techniques over the body politic, this "condition of knowledge" (24) translated into identifying evidence of God's grace and therefore laying out common criteria of authenticity while preserving the originality of each individual statement. In other words, in order to avoid accusations of hypocrisy or heresy, individual knowledge had to be made available as communal knowledge without being stripped of its singularity through its molding into a legible, standardized form (71). Yet what singled New England out was not so much the intertwining of religion and science in the quest for signs of election, as the social and political consequences it involved. In particular, Rivett shows how the morphology of New England testimonies of faith was predicated upon a "masculine form as the ideal testimonial witness of grace in contrast to the patterns of shyness, reluctance, and silence" evidenced by women and leading to their exclusion from the body of the church as well as the body politic (74). Where men engaged in "a pedagogy of transparency" (105) and displayed no doubt as to the certainty of their election, women often refrained from such self-exposure and voiced a "condition of incertitude" (117) that both spurred the desire for further knowledge within the community and sanctioned their spiritual and social inferiority. Similarly, the interest of John Eliot and Roger Williams for "Praying Indians," as they came to be called, and for the Indian languages revealed their commitment to a form of spiritual ethnography in accordance to the principles of early modern empirical science and natural philosophy, even as the testimonies they produced remained generic and conventional, thus failing to offer the required individualized experience and relegating Indian populations in a subaltern position. In the cases of women and Praying Indians, at least until the Halfway Covenant of 1662, "the science of the soul" was thus an instrument of social control and gender and racial realignments, as much as a vehicle for theological and scientific knowledge.

3 Rivett then turns to the end of the seventeenth century to explore deathbed confessions of women, young children and Native Americans, a form of narration she calls "tokenography" (178). In keeping with her overall empiricist claim, she contends that the appeal of these populations for ministers and scientists stemmed from the philosophy of Locke since "they most closely resemble[d] the tabula rasa state" (180). Her contrastive reading of Ann Bradstreet's "Contemplations" and Locke's Essay Concerning Human Understanding (195-200), echoed later on in the book by her striking parallel between Ann Hutchinson's antinomian claim and Descartes's Discourse on Method (both dating from 1637 [232]), deftly buttresses her argument for a transatlantic and interdisciplinary study of "the science of the soul" in the early modern world. Likewise, she interprets the 1692 Salem witch trials and controversies about the workings of the devil as "a phase of an emerging Enlightenment modernity," rather than "a symbol of a fading occult worldview," and reminds us shrewdly that Cotton Mather was also a contemporary of Spinoza (226). Contrary to a now widely held view 
of the end of the seventeenth century as the watershed time of a "Radical Enlightenment," founded upon the divorce between past and present, religion and science, the invisible and the visible, Rivett proposes a mirror version of Enlightenment where "empiricism could be used to chart the unseen" (230). Trying to prove the existence of the devil by means of empirical testimonies was not a relic of medieval superstitions, therefore, but an attempt to push back the boundaries of knowledge using the latest methods of scientific investigation.

4 The last chapter focuses on the figure of Jonathan Edwards whose congregants' testimonies of faith are seen both as a persistence of a genre that was generally on the wane in the early decades of the eighteenth century and as a transformation of earlier patterns of evidence. Among the most salient differences between earlier testimonies and Edwards's revival accounts, Rivett emphasizes in particular the new imagery of darkness and light that was woven into these later records and that she considers a telltale sign of "an era concerned with enlightenment" (276). She also insists on the new mirroring relation between the soul, nature and the divine elicited in these testimonies, which allows her to position Edwards as simultaneously "embedded in transatlantic culture" and "geographically bound, first to New England and then to America as a particular spiritual place" (281-82).

5 Titled "Conversion in America," thus recalling nicely Patricia Caldwell's The Puritan Conversion Narrative: The Beginnings of American Expression, ${ }^{1}$ the book's conclusion reflects on the notion of "American religious genres," among which the jeremiad, the captivity narrative and the testimony of faith (346), which Rivett connects both to their colonial precedents and to a wider transatlantic culture, even as she sketches their adaptation to an increasingly secular age in the course of the eighteenth century, thus testifying, like Sacvan Bercovitch and others before her whose contribution she acknowledges and complements, ${ }^{2}$ to the resilience of the genres and their lasting and formative impact upon the national character.

The Science of the Soul is a thoroughly researched and elegantly written study that demonstrates magisterially how globalized the quest for knowledge already was in the early modern age. Mining through a wide array of texts and contexts, juxtaposing towering figures of modernity, such as Francis Bacon, Robert Boyle, Descartes, Locke, and Spinoza, with New England notables like John Winthrop or Increase and Cotton Mather, and lesser known ministers, scholars, and visible saints, Sarah Rivett renews our understanding, not only of Colonial New England, but also of early modern Europe and of the Enlightenment, while opening up fruitful avenues to reflect on the role of theological and epistemological enquiries in the formation of American print culture.

\section{NOTES}

1. Patricia Caldwell, The Puritan Conversion Narrative: The Beginnings of American Expression, Cambridge, Cambridge University Press, 1983. 
2. See for instance Sacvan Bercovitch, The American Jeremiad, Madison, University of Wisconsin Press, 1978 and The Rites of Assent: Transformation in the Symbolic Construction of America, New York, Routledge, 1993, but also Alan Heimert, Religion and the American Mind: From the Great Awakening to the Revolution, Cambridge, Harvard University press, 1996 and Ann Taves, Fits, Trances, and Visions. Experiencing Religion and Explaining Experience from Wesley to James, Princeton, Princeton University Press, 1999.

\section{AUTEURS}

\section{THOMAS CONSTANTINESCO}

Université Paris Diderot 